\title{
Experimental Fluid Mechanics 2012
}

TU Liberec, Czech Republic, 20 ${ }^{\text {th }}-23^{\text {rd }}$ November 2012

$7^{\text {th }}$ International Conference ,Experimental Fluid Mechanics 2012” was held at $20^{\text {th }}-23^{\text {rd }}$ of November 2012 in Hradec Králové, Czech Republic.

The conference is focused on obtaining overviews of projects under investigation and experimental methods used in the field of fluid mechanic and thermodynamic. Its aim is to organize a network of research workers who are interested in experimental, and also theoretical, work in the field of fluid mechanic and thermodynamic. The conference should contribute the creation of closer contacts and sharing experience in application of various experimental methods, preparation and implementation of experiments, processing of results and numerical simulations of experiments.

The main topics of the conference are:

- Experimental methods used in fluid mechanics and thermodynamics.

- Preparation and implementation of experiments.

- Application of numerical simulation for preparation of experiments, comparison of the results obtained by numerical or analytical methods with experiments.

- Processing the results.

- Experiments in the field of compressible and uncompressible fluid flow, stability of flow, heat and mass transfer, cavitation etc.

- Experiments and measuring carried out on power and regulating equipment.

- Cryogenic fluid dynamics.

Members of Sciences Committee are:

- Assoc. Prof. Tomáš Vít - Head of the committee (TU Liberec, Czech Republic)

- Prof. An-Bang Wang (National Taiwan University, Taiwan)

- Prof. Philippe Fraunie (Université du Sud Toulon-Var, France)

- Prof. Ladislav Skrbek (Charles University, Czech Republic)

- Prof. Václav Kopecký (TU Liberec, Czech Republic)

- Assoc. Prof. Hendric de Lange (Eindhoven Univ. of Technology, The Netherlands)

- Assoc. Prof. Kazimierz Perszynski (Univ. of Technology and Life Sciences in Bydgoszcz, Poland)

- Assoc. Prof. Ludvík Prášil (TU Liberec, Czech Republic)

- Dr. Jan Hrubý (Academy of Science of Czech Republic)

- Dr. Magda Vestfálová (TU Liberec, Czech Republic)

Steering Committee:

- Dr. Petra Dančová (TU Liberec, Czech Republic)

- Eng. Petr Novotný (TU Liberec, Czech Republic)

List of Sponsors (in alphabetical order):

- DANTEC DYNAMICS GmbH (www.dantecdynamics.com)

- KAMAX Holding (www.kamax.com) 

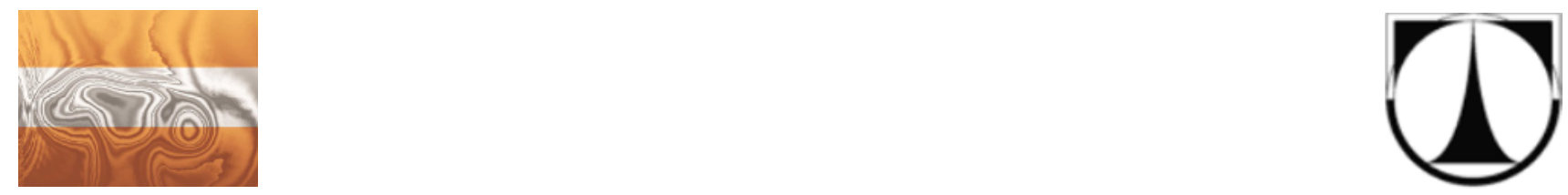

- LENAM s.r.o. (www.lenam.cz)

- MIT s.r.o. (www.mit-laser.cz)

- SPECION s.r.o. (www.specion.biz)

\section{Conference venue:}

Every year, the organizers want to prepare the conference at nice and interesting place of the Czech Republic. In 2012 the conference venue was Hradec Kralové. The city Hradec Králové is situated in the center of a very fertile region called the Golden Road on the confluence of Elbe and Orlice and contains many buildings of historical and architectural interest. During the 1920s and 1930s the city grew rapidly and due to many buildings of modern architecture Hradec Králové became known as the Salon of the Republic. This was a nickname given to it by citizens who were spellbound by the unique architecture of Josef Gočár.

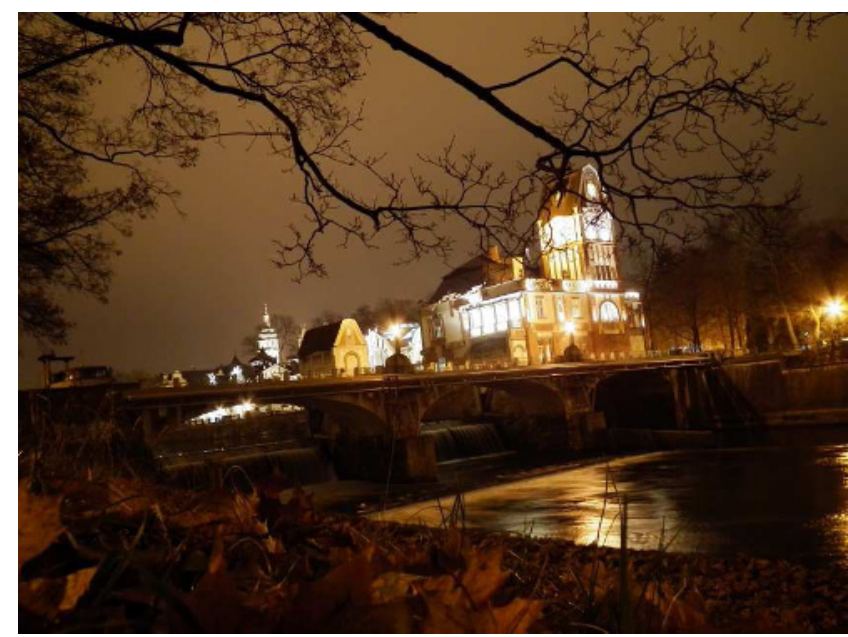

Historical Hydro Power Station in Hradec Kralove place of Plenary Session (C) and Informal gathering

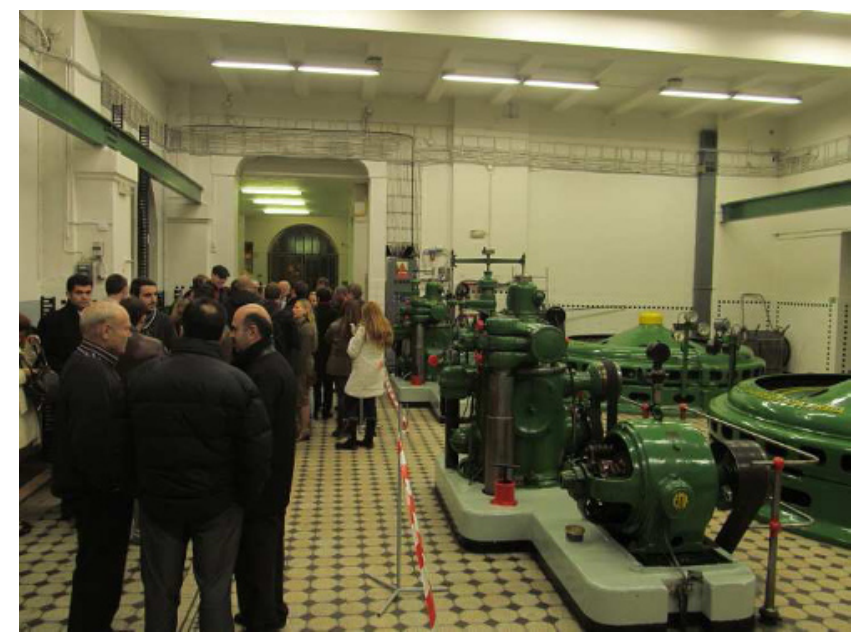

Excursion into Historical Hydro Power Station in Hradec Kralove

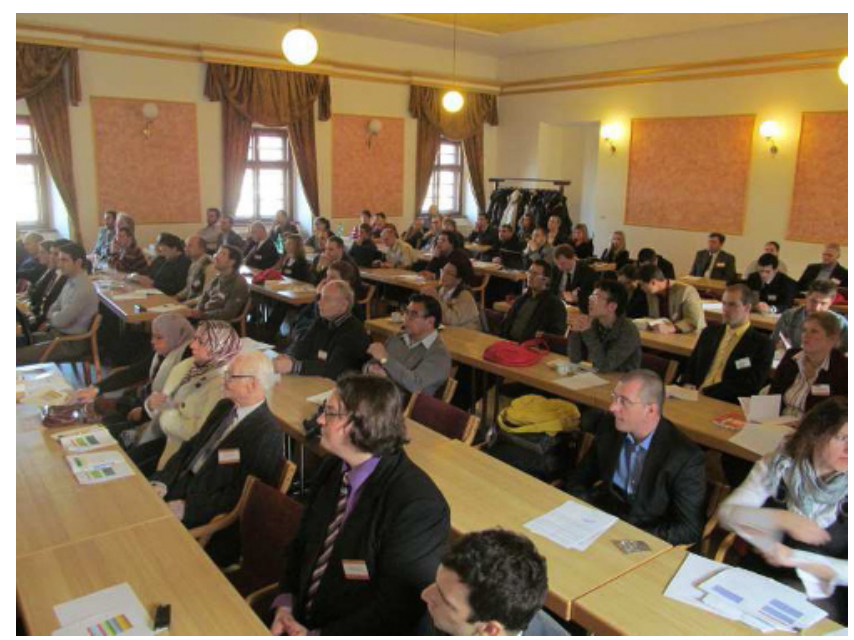

View into a Lecture Room 